\title{
The Focus Of Tax Instruments In Reducing Emissions From Electricity Generation In Selected Developing Countries
}

Mareli Dippenaar, Stellenbosch University, South Africa Rudie Nel, Stellenbosch University, South Africa

\begin{abstract}
The objective of the study was to determine the primary focus of selected developing countries (four BRICS countries; namely, Brazil, China, India and South Africa) in applying tax instruments to reduce their emissions from electricity generation. The focus of tax instruments could be on supply or demand; incentives or disincentives; direct or indirect taxes; and renewable energy, energy efficiency or research and development in these fields. It was found that the tax instruments in South Africa and India focus almost equally on the supply and demand of electricity, while the tax instruments in China focus on the demand side and those in Brazil place slightly more emphasis on the supply side. The primary focus in all the countries studied appears to be the application of incentives, rather than disincentives and the focus of their tax incentives appears to fall equally on the application of direct and indirect taxes, with the exception of South Africa where hardly any indirect tax incentives are applied. Furthermore, there seems to be an almost equal focus on renewable energy, energy efficiency and research and development in the countries studied, with the exception of China where the number of tax instruments specifically aimed at energy efficiency significantly exceeds the number of instruments specifically aimed at renewable energy and research and development. Based on the findings, Brazil does not apply tax instruments to target energy efficiency.
\end{abstract}

Keywords: Tax Instruments; Tax Incentives; Tax Disincentives; Indirect Taxes; Electricity Supply; Electricity Demand; South Africa; China; Brazil; India; Renewable Energy; Energy Efficiency

\section{INTRODUCTION}

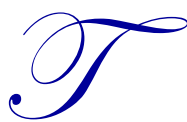

here is not a single country in the world that remains unaffected by climate change caused, inter alia, by the emission of greenhouse gases (hereafter referred to as "emissions"). The power generation and road transport sectors have contributed the largest growth in global carbon dioxide $\left(\mathrm{CO}_{2)}\right.$ emissions since 1970, with emissions from the energy supply sector having grown by over 145 percent since then. By 2004, $\mathrm{CO}_{2}$ emissions from power generation represented over 27 percent of the total global anthropogenic $\mathrm{CO}_{2}$ emissions (Metz, Davidson, Bosch, Dave \& Meyer, 2007). Urgent change is therefore needed and government intervention is necessary. There are many different government approaches and instruments that can be applied to reduce the emissions from electricity generation and, frequently, a combination of instruments, which might include tax instruments, will be most effective (Republic of South Africa, 2006; Bierbaum \& Friedman, 1992; Nteo, 2012; Winkler, 2005).

In order to address the issue of increasing emissions from electricity generation, either the demand for, or the supply of, electricity, or both, could be addressed. This would contribute to the reduction of the demand for electricity generated from sources with high emissions and/or the increase of the supply of electricity from renewable sources with fewer emissions. The initial costs of generating electricity from renewable sources are high (Buffkins, 2012) and it is therefore difficult for these forms of electricity to compete with coal-generated electricity, for example. Tax incentives, combined with other instruments, could, however, stimulate investment in renewable 
energy (RE) (Centre for Resource Solutions [CRS], 2005). Tax instruments in the form of incentives for energy efficiency (EE) (Lomas, 2012) or penalties (disincentives) for using non-renewable electricity (Bierbaum \& Friedman, 1992) can potentially play a role in managing the demand for electricity. Tax incentives also have the potential to encourage investment in research and development (R\&D) of technologies for electricity generation and use that limit emissions, such as RE and EE technologies (KPMG, 2013b). Throughout the study, the term "tax instruments" is applied as a collective noun for tax incentives, tax disincentives, or both.

Although tax instruments are not the only tools that can address the challenge of reduction in emissions (Bierbaum \& Friedman, 1992; Giraudet, Guivarch \& Quirion, 2011), they could potentially play an important role (Ashiabor, 2005). Some economists and researchers argue that tax incentives are generally redundant and ineffective when trying to stimulate investment (Bird, 2008; Easson \& Zolt, 2002). However, tax incentives are still widely used, even though the empirical evidence on the cost-effectiveness thereof is highly inconclusive (Zee, Stotsky \& Ley, 2002; Nathan-MSI Group, 2004). Nteo (2012) and the Nathan-MSI Group (2004) point out that the most effective instrument would depend on a country's specific circumstances and governments should exercise judgement when selecting appropriate instruments. Although there are mixed opinions about the use and effectiveness of tax incentives, they still drive much of the tax policy in both developing and developed countries (Calitz, Wallace \& Burrows, 2013).

It is common for governments searching for policy solutions to new or changing problems to consider policies in other countries (Dolowitz \& Marsh, 2000) and therefore a comparison between countries could assist the respective policymakers. It is submitted that the effects of global warming are likely to impact stronger on developing than developed countries (Ahuja \& Tatsutani, 2009) and therefore the comparison is performed between developing countries. Developing countries are likely to experience the countless problems associated with global warming more severely because of their sensitivity to such adverse impacts. Furthermore, these countries are less likely to have the resources, both financial and institutional, to effectively adapt in such circumstances and would not be able to escape the potentially significant adverse consequences of their energy challenges, which include reducing their energy-related emissions, unless their governments intervene (Ahuja \& Tatsutani, 2009). Many industrialised countries have been relocating their carbon-intensive manufacturing activities to developing countries for various reasons, thereby worsening the problem for the latter. This has led to increased pressure for the developing countries to increase their environmental protection efforts and embark on more sustainable development pathways (Weiss \& Jacobson, 1998; Blackman \& Sisto, 2006, cited in Freitas, Dantas \& Iizuka, 2011). Although all developing countries are not the same, these countries do face similar economic challenges and have similar goals (Todaro, 2000).

There is also an on-going shift in RE activity from developed to developing countries. During 2012, investment in RE in developing countries increased by 19 percent, while investment in developed countries decreased by 29 percent in the same year. China and South Africa, inter alia, experienced sharp increases in RE investment in 2012, with China being the top scorer globally in respect of RE investment in 2009, 2010 and 2012 (Bloomberg New Energy Finance, 2011 \& 2013). India, South Africa and Brazil also made significant investments in RE and were seventh, eighth and ninth, respectively, in RE investment in 2012 (Bloomberg New Energy Finance, 2013). According to the United Nations Industrial Development Organization (UNIDO, 2009), Brazil, India and China are examples of countries where government policies have assisted in establishing a RE market. Not only are the four selected countries; namely, Brazil, China, India and South Africa, actively promoting RE, they are actively using tax instruments to achieve their green policy objectives (KPMG, 2013b). In addition, the four selected countries are all developing countries with electricity supply shortages and very high emissions from the burning of fossil fuels and all have committed to reduce their emissions. The selected countries also all form part of the BRICS association of major emerging economies - Brazil, Russia, India, China and South Africa. The BRICS countries have unique economic characteristics and the association was formed in order to leverage on their trading characteristics (Nteo, 2012). The BRICS countries are largely dependent on fossil fuels and the per capita carbon emissions of this group of countries are relatively high - roughly two-thirds of the global average. These countries have similar ambitions for human development and social improvement, but the funds invested in education, health and infrastructure, as a percentage of their savings, vary significantly among them (May, 2008). The BRICS countries are experiencing significant challenges to the continued growth of their economies, but without proportionately large increases in their emissions (Freitas et al., 2011). 
Finally, Brazil, China, India and South Africa are all non-Annex countries in the Kyoto Protocol, while Russia is an Annex I country. As a result, Russia has very different responsibilities in terms of the protocol than the other countries. The protocol is an international agreement linked to the United Nations Framework Convention on Climate Change that sets internationally binding targets for the reduction of emissions on Annex I and II countries (UNFCCC, 2014), while non-Annex countries are merely encouraged to voluntarily reduce their emissions. Russia is likely to have very different government policies for addressing climate change challenges than the other BRICS countries, which is likely to make Russia less comparable; therefore, Russia is excluded from the study. In further support of this exclusion, the other four BRICS countries, excluding Russia, have formed a group called BASIC - an emerging geopolitical alliance to strengthen their negotiating muscle (Nteo, 2012) as they committed themselves to act jointly at the United Nations Climate Change Conference in Copenhagen in 2009 (Dasgupta, 2009).

\section{RESEARCH OBJECTIVE, RESEARCH METHODOLOGY AND SCOPE}

The objective of this study is to compare the tax instruments that are applied to indirectly contribute to the reduction of emissions from the generation of electricity in selected developing countries in order to determine the primary focus thereof. Four members of the BRICS association of countries; namely, Brazil, China, India, and South Africa, were chosen for this comparison. Tax perspectives on both the demand by consumers and the supply by producers of electricity are investigated. The following specific research questions will be addressed, with reference to available literature:

- $\quad$ Do the selected countries primarily focus on addressing the demand or the supply of electricity?

- $\quad$ Do the selected countries primarily apply tax incentives or disincentives?

- $\quad$ Do the selected countries primarily apply direct or indirect taxes?

- $\quad$ Do the selected countries primarily focus on addressing RE, EE, or R\&D?

This study would contribute to the existing academic literature regarding tax incentives by being the first to formalise a response to the above primary focus questions. The findings are considered relevant for policymakers as it could potentially highlight areas for improvement or, at the very least, for consideration by these countries. The study also serves as précis of tax instruments in the selected countries that could assist investors in RE or EE technologies and taxpayers to understand the tax instruments currently available in these countries. The research performed in this study entails a literature review of statutory law, accredited and non-accredited articles, books and dissertations.

In order to determine the primary focus of the tax instruments applied by the selected countries, only currently effective tax instruments are considered. Furthermore, the comparison between countries is performed regardless of the possible financial impact of the instruments, the effectiveness of the instruments in changing behaviour, the remaining effective period of the instruments and the ease of compliance with the requirements of the respective instruments. As only literature written in English is considered, it is recognised that sources in other languages could contain tax proposals relevant to this study, but this could serve as a basis for expansion in future research by other researchers proficient in such other languages.

The study commences with a brief background of electricity generation in each of the selected countries and a précis of the applicable tax instruments identified which relate to electricity generation. This is followed by a determination of the primary focus of these tax instruments by performing a comparison between the different selected countries. The study then concludes by formalising a response to each of the specific research questions.

\section{Tax Instruments Applied In Selected Developing Countries}

Brazil

Unlike many other developing countries where the energy sector accounts for the majority of the countries' total emissions, Brazil's largest source of emissions is its agricultural industry. Although Brazil's energy sector experienced the fastest growth in emissions of all sectors in the country during 2012, the sector is still regarded as environmentally friendly when compared to the energy sectors of the majority of other major economies (Tollefson, 
2013). Brazil is committed to developing its RE industry (Chacon, 2013) and has made significant investments in RE - it ranked ninth worldwide in terms of RE investment in 2012 (Bloomberg New Energy Finance, 2013). RE sources account for 46 percent of the primary energy production in Brazil (Ministry of Mines and Energy, 2013) compared to a global average of just over 13 percent (United Nations Environment Programme, 2012).

The Brazilian government applies some tax instruments to achieve green policy objectives but is ranked $18^{\text {th }}$ overall out of 21 countries featured in KPMG's green tax index, indicating that Brazil is less active in using tax instruments to achieve its green policy objectives than the majority of the other countries listed in the index (KPMG, 2013b). The United Nations Industrial Development Organization (UNIDO, 2009) identified Brazil as a country where government policies have assisted in establishing an RE market. Although tax incentives did assist in stimulating additional investment under Brazil's Incentive Programme for Alternative Sources of Energy, the programme is regarded as having successfully encouraged investors to commit resources to RE projects without relying on tax incentives (Chacon, 2013).

Brazil utilises various tax instruments relating to corporate income tax, social contribution taxes ${ }^{1}$, federal value-added tax $(\mathrm{VAT})^{2}$, state $\mathrm{VAT}^{3}$, and federal social contributions ${ }^{4}$ to contribute to the reduction of emissions associated with electricity generation in the country. Following are current effective tax instruments that were identified in Brazil.

\section{Instruments That Specifically Target Supply}

- $\quad$ Equipment used to generate RE is generally exempt from federal VAT (KPMG, 2013a).

- $\quad$ Assets used to generate wind or solar energy are granted an exemption from state VAT (KPMG, 2013a).

- A five-year exemption of federal social contributions is granted in respect of the acquisition and importation of certain assets and services by qualifying companies engaged in certain sectors, which include the generation of electricity (Farah, 2013), and, consequently, RE generators could possibly qualify for these incentives.

\section{Instruments That Specifically Target Demand}

\section{- $\quad$ None}

\section{Instruments That Target Both Supply And Demand}

- $\quad$ Companies whose activities fall into economic segments considered by the government to be a priority for the development of the Amazon or North-Eastern regions are entitled to a reduced corporate income tax rate for ten years (PWC, 2013a). Both RE and EE projects could potentially qualify (KPMG, 2013a).

- $\quad$ Companies that undertake qualifying R\&D activities, which could be in respect of RE or EE, and incur qualifying R\&D expenditures, benefit from 160 to 200 percent super allowances (Deloitte, 2013a).

- $\quad$ Accelerated depreciation allowances are granted in respect of new assets acquired and exclusively dedicated to $R \& D$, including intangible assets. Such assets qualify for a 100 percent depreciation allowance in the year of acquisition (Deloitte, 2013a).

- $\quad$ A 50 percent reduction in federal VAT is granted in respect of assets acquired and used in qualifying R\&D activities (Deloitte, 2013a).

There are no tax disincentives and only seven tax incentives applied by the Brazilian government to target

\footnotetext{
${ }^{1}$ The social contribution tax is referred to as CSLL in Brazil.

${ }^{2}$ The industrialised product tax called IPI is an excise tax levied by the federal government on the manufacture and importation of goods into Brazil and is similar to a type of VAT.

${ }^{3}$ ICMS is a VAT levied by state governments on the circulation and importation of goods and the provision of inter-state and inter-municipal transportation and communication services and is hereafter referred to as "state VAT".

${ }^{4}$ PIS and COFINS (federal social contributions) are levied on gross income and operate as non-cumulative VAT-type taxes for certain taxpayers.
} 
the emissions by the electricity sector. There are slightly more indirect tax incentives (four) than there are direct tax incentives (three). A few of the incentives identified are general incentives and do not specifically target RE or EE. Although RE or EE projects could potentially qualify for these general incentives, electricity generation from conventional sources could also potentially qualify for some of these incentives. Only two instruments specifically target RE and three target R\&D. Although there are no instruments that specifically target EE, there are a few general incentives for which EE could potentially qualify. There appears to be slightly more focus on the supply of electricity than the demand for electricity, with seven instruments targeting supply and only four targeting demand.

\section{China}

Globally, China was the biggest investor in RE in 2009, 2010 and 2012 (Bloomberg New Energy Finance, $2011 \& 2013$ ) and the country's wind industry has been growing at an unprecedentedly high rate since 2004. This growth is largely attributed to the effective implementation of a combination of domestic policies, which include the application of tax incentives and international support (Zhang, Chang, Huo \& Wang, 2009). According to KPMG's green tax index, China ranks sixth overall out of the 21 countries studied, indicating that its government is actively using tax instruments to promote a greener economy (KPMG, 2013b). China has had a long history of using financial incentives and penalties to encourage desired outcomes (Seligsohn, Heilmayr, Tan \& Weischer, 2009) and is an example of a country whose green tax policy is balanced between carrots and sticks (KPMG, 2013b).

China utilises various tax instruments relating to enterprise tax ${ }^{5}$, VAT, business tax ${ }^{6}$, and import tax and duties to contribute to the reduction of emissions associated with electricity generation in the country. Following are current effective tax instruments that were identified in China.

Instruments That Specifically Target Supply

- Wind farm developers are entitled to a 50 percent refund of VAT on the sale of self-manufactured electric power generated from wind power (KPMG, 2013a).

- $\quad$ Certain wind and hydro power generation components imported qualify for an exemption from customs duty (Chadbourne \& Park, 2010; Jungfeng, Pengfei \& Hu, 2010).

\section{$\underline{\text { Instruments That Specifically Target Demand }}$}

- $\quad$ A qualifying energy service company (ESCO) is entitled to a three-year enterprise tax exemption, followed by another three years of paying tax at a reduced rate, starting from the year in which the revenue from the energy management contract ${ }^{7}$ (EMC) project first arises (KPMG, 2011).

- Any contribution received by an ESCO, in respect of assets transferred to the energy user at the end of the term of the EMC, is exempt from enterprise tax (KPMG, 2011).

- $\quad$ The energy user in an EMC project is entitled to an allowance in respect of the reasonable expenditures actually incurred in accordance with the EMC project (KPMG, 2011).

- $\quad$ Enterprises that invest in special equipment for energy conservation and use the equipment itself are entitled to an enterprise tax credit of ten percent of the investment amount (KPMG, 2011 \& 2013a).

- Where income is derived from qualifying environmental protection and energy conservation projects, the enterprise is eligible for a three-year enterprise tax exemption, followed by another three years of paying tax at a reduced rate (KPMG, 2013a).

- $\quad$ An ESCO's revenue received in an EMC project is exempt from business tax (KPMG, 2013a).

- $\quad$ An ESCO's revenue derived from an EMC project is exempt from VAT (KPMG, 2013a).

\footnotetext{
${ }_{6}^{5}$ Enterprise tax is imposed on the taxable income of corporations.

${ }^{6}$ Business tax is imposed on the turnover from the sale of immovable property and intangible goods, as well as on certain services that are not subject to VAT. VAT is imposed on the sale or importation of goods and the provision of processing, repair and replacement services within China. Consequently, business tax and VAT are mutually exclusive (Deloitte, 2013b).

${ }^{7}$ Also known as energy performance contracts. An energy management contract is a mechanism whereby an energy user enters into an agreement with an energy service company that undertakes to provide the necessary services to help the energy user reduce its energy consumption (KPMG, 2011).
} 
- If an ESCO transfers assets related to an EMC project to the energy user in the project, the transfer is exempt from VAT (KPMG, 2011).

- $\quad$ Equipment imported for self-use in certain domestic- and foreign-invested projects that are encouraged by the state, such as the development of energy savings technologies, is exempt from import duty (KPMG, 2011).

Instruments That Target Both Supply And Demand

- $\quad$ High and new technology enterprises ${ }^{8}$ (HNTEs) pay enterprise tax at a reduced rate. Companies in the fields of RE, energy conservation, or R\&D could potentially qualify for the incentive (KPMG, 2012; 2013a).

- $\quad$ An HNTE in a special economic zone, qualify for a two-year enterprise tax exemption, followed by another three years of paying enterprise tax at a reduced rate (EY, 2013a).

- A portion of the proceeds derived from the sale of certified emission reductions (CERs) from clean development mechanism (CDM) projects, which could include RE or EE projects, should be remitted to the Chinese government in accordance with certain specified ratios (KPMG, 2009). This portion of the proceeds is deductible for enterprise tax purposes (KPMG, 2013a).

- $\quad$ Certain donations and interest income received by CDM enterprises are exempt from enterprise income tax (KPMG, 2013a).

- $\quad$ Chinese residents undertaking qualifying $R \& D$ activities, which could include RE or EE, are entitled to a 150 percent allowance in respect of qualifying R\&D expenditure incurred (KPMG, 2012).

- $\quad$ Specified $R \& D$ equipment imported by qualified foreign-invested R\&D centres is exempt from VAT (KPMG, 2012).

- $\quad$ Specified R\&D equipment imported by qualified foreign-invested R\&D centres is exempt from customs duty (KPMG, 2012).

- Input VAT relating to equipment manufactured in China and purchased by qualified domestic R\&D institutes and foreign-invested R\&D centres is refundable (KPMG, 2012).

The tax incentives consist almost equally of direct (ten) and indirect (nine) taxes. All 19 of the tax instruments encourage environmentally good behaviour and there are currently no tax disincentives. The government appears to be more focused on the demand for, than the supply of, electricity, with 17 instruments targeting demand and only ten targeting supply. This difference is largely attributed to the numerous incentives for EMC projects. Two instruments are focused on RE - eight on EE specifically and four on R\&D specifically. Once again, the large number of instruments specifically targeting $\mathrm{EE}$ is primarily attributable to the various incentives available for EMC projects.

India

India is the third largest greenhouse gas emitter globally (World Bank, 2013). Within India, the largest emitter is the country's energy sector (Upadhyaya, 2010). In 2007, the electricity generation sector was responsible for 37.8 percent of the total emissions in India - a percentage significantly higher than the emissions by the other sectors (Ministry of Environment and Forests, 2010). Access to energy is the Indian government's primary objective, as almost one-quarter of the population lacks access to electricity (International Energy Agency, 2012). Electricity generated from coal represents 55 percent of the total electricity generated in India, while electricity from renewable sources only accounts for about 11 percent of the total electricity (Bana, 2012). This percentage from renewable sources is likely to increase in the future, as the government requires state electricity distributors to purchase a minimum percentage of electricity from renewable sources (Upadhyaya, 2010).

According to the Ministry of New and Renewable Energy (MNRE, 2013), RE occupies a central place in India's National Action Plan on Climate Change. Significant investments have been made in RE and, according to Bloomberg New Energy Finance (2013), India ranked seventh globally in terms of investments in RE in 2012. The

${ }^{8}$ Also referred to as advanced and new technology enterprises 
growth in India's RE sector has been encouraged by a variety of policy and support measures taken by the government, including financial incentives (Chandrasekar \& Kandpal, 2004), fiscal policies such as tax incentives, preferential tariffs for renewable electricity, and other promotional policies (Singh, 2007).

India utilises various tax instruments relating to corporate income tax, customs and excise duties, $\mathrm{VAT}^{9}$, sales $\operatorname{tax}^{10}$, and service tax ${ }^{11}$ to contribute to the reduction of emissions associated with electricity generation in the country. Following are current effective tax instruments that were identified in India:

\section{Instruments That Specifically Target Supply}

- $\quad$ Accelerated depreciation allowances of 80 percent of the cost of certain RE-generating assets are granted to companies involved in RE (KPMG, 2013a \& 2013b; PWC, 2013b; EY, 2013a).

- Companies engaged in the generation and/or distribution of power, including electricity generated from renewable sources, are entitled to a ten-year tax holiday providing that the power generation began before 31 March, 2014. However, such companies still have to pay a minimum alternative $\operatorname{tax}^{12}$ (MAT) (KPMG, 2013a; Bana, 2012).

- $\quad$ Specified RE goods qualify for exemptions or concessions of customs duties (KPMG, 2013a; Sinha, 2011; Rewave Infra Solutions, 2013).

- $\quad$ Specified RE goods qualify for exemptions or concessions of excise duties (KPMG, 2013a; Sinha, 2011; Rewave Infra Solutions, 2013).

- $\quad$ Some state governments offer significantly reduced VAT rates or VAT exemptions in respect of RE components (KPMG, 2013a; Rewave Infra Solutions, 2013).

\section{$\underline{\text { Instruments That Specifically Target Demand }}$}

- Companies that purchase certain energy-saving devices are entitled to an accelerated depreciation allowance of 80 percent of the cost of such devices in the year of acquisition (KPMG, 2013b).

- India has a nationwide carbon tax on coal of 50 rupees per ton of coal produced in, or imported into, India (KPMG, 2013b). This tax could potentially increase the cost of coal which could, in turn, potentially increase the cost of electricity generated from coal. Such an increase in the cost of electricity could serve as a price signal and possibly incentivise electricity consumers to reduce their demand for electricity, especially electricity generated from coal.

\section{Instruments That Target Both Supply And Demand}

- $\quad$ Companies engaged in qualifying R\&D activities, which could be in respect of RE or EE, are entitled to a 100 or 200 percent allowance in respect of qualifying $R \& D$ expenditures incurred. A 100 percent allowance is also available in respect of certain pre-trade expenditure (Deloitte, 2013a; EY, 2013b).

- $\quad$ Companies that make donations or contributions to other specified entities for R\&D are entitled to a 125 to 200 percent allowance (EY, 2013b).

- $\quad$ A company that sets its $R \& D$ unit up in a special economic zone and that exports its $R \& D$ services are entitled to a 15 -year phased tax holiday on all profits earned from such $R \& D$ services. However, such units are still liable for MAT (EY, 2013b).

- $\quad$ Companies and certain research institutions that import specified R\&D assets qualify for customs duty exemptions or reductions on the purchase of such assets (EY, 2013b).

- $\quad$ Research institutions that acquire specified $R \& D$ assets that were manufactured in India qualify for excise

\footnotetext{
${ }^{9}$ Vat is levied by the central government on goods manufactured in India.

${ }^{10}$ Sales tax is levied on goods, either by the central government on interstate sales or by the state governments, on intrastate sales (the latter is a type of VAT, referred to as "state VAT").

${ }^{11}$ Service tax is levied on certain services, such as specified banking and other financial services, insurance, scientific or technical consultancy, information technology services, telecommunication services and services performed by consulting engineers and management consultants.

${ }^{12}$ Should a company's income tax liability be less than 18.5 percent of its book profit, as defined, including access and applicable surcharges, a minimum alternative tax becomes payable (EY, 2013a).
} 
duties exemptions (EY, 2013b).

- $\quad$ Special economic zones, which can include R\&D in respect of RE or EE, are eligible for various indirect tax benefits (Ministry of Commerce and Industry, 2009; PWC, 2012; KPMG, 2013c), including:

$\circ \quad$ Customs and excise duties exemptions

- Central government sales tax abatements or exemptions

- Upfront exemptions from service tax and, in certain circumstances, even refunds

$\circ \quad$ Exemptions from state VAT and other levies, as extended by the respective state governments

Based on the aforementioned, there are four instruments that specifically target RE - two that specifically target EE, including a carbon tax on coal, and five that specifically target R\&D. The Indian government applies direct and indirect taxes almost equally to achieve its green policy objectives. There are nine indirect and six direct tax incentives currently in use. India more actively uses tax incentives than it uses tax penalties to achieve its environmental objectives; there are currently 15 different incentives and only one disincentive (the carbon tax on coal). There appears to be equal focus on the demand for, and the supply of, electricity as there are 14 instruments aimed at the supply and 11 aimed at the demand.

South Africa

The electricity supply in South Africa is under significant strain; the country's economy has been growing significantly over a large number of years, leading to significantly higher electricity demand. However, the electricity supply has not been growing sufficiently to provide for this increased demand. South Africa remains heavily reliant on the country's inexpensive and abundant coal to generate electricity, but using coal has significant weaknesses, including the polluting effects of emissions. However, the South African government has committed to reducing its emissions by 2025 and is focussed on improving its EE. In addition, it plans to diversify the country's energy supply and is encouraging the application of RE technology (Republic of South Africa, 2004, 2009 \& 2012).

South Africa applies of various tax instruments to contribute to the reduction of emissions associated with electricity generation in the country. Following are current effective tax instruments that were identified in South Africa.

Instruments That Specifically Target Supply

- In terms of section 12B of the Income Tax Act no. 58 of 1962 (the Income Tax Act), accelerated depreciation allowances are granted in respect of assets used in the production of renewable electricity. The allowance is granted over three years in the ratio 50:30:20 based on the cost of the assets.

- In accordance with schedule no.1, part 1 of the Customs and Excise Act no. 91 of 1964 (Customs and Excise Act), certain items related to the generation of wind energy are exempt from customs duties when imported.

- An environmental levy of 3.5 cents per kilowatt hour $(\mathrm{kWh})$ is levied on electricity generated from nonrenewable sources in terms of section 54A and schedule no.1, part 3B of the Customs and Excise Act. It is likely that the levy is simply passed on to the consumers since electricity is relatively price inelastic. However, electricity is a necessity rather than a luxury; therefore, it is unlikely that the increased electricity price will significantly reduce the demand. Furthermore, consumers cannot choose where to buy their electricity and do not have an alternative supplier of renewable electricity. Although it could be regarded as a demand-side instrument, it appears as if government's intention was to target the suppliers since the environmental levy is levied on the generators of non-renewable electricity. Consequently, it is regarded as a supply-side disincentive for the purposes of the analysis of the primary focus of the tax instruments applied in South Africa. 
Instruments That Specifically Target Demand

- A notional allowance is granted in terms of section 12L of the Income Tax Act based on energy savings achieved by EE projects. The allowance is calculated as 45 cents per $\mathrm{kWh}$ (or equivalent) of energy savings during the year of assessment, made against a baseline measured at the beginning of the year.

- $\quad$ Section 12I of the Income Tax Act provides an allowance of 35 to 100 percent in respect of the cost of new and unapplied manufacturing assets used in industrial policy projects that use improved EE and cleaner production technology, inter alia. This allowance is limited to very large projects only.

- $\quad$ An environmental levy of 400 cents per light bulb is levied in terms of section 54A and schedule no.1, part 3C of the Customs and Excise Act, on incandescent light bulbs to encourage EE and reduce the demand for electricity.

Instruments That Target Both Supply And Demand

- $\quad$ The proceeds from the sale of CERs from approved CDM projects, which could include RE or EE projects, are exempt in terms of section $12 \mathrm{~K}$ of the Income Tax Act.

- Section 11D of the Income Tax Act grants a 150 percent allowance in respect of expenditure incurred on R\&D activities undertaken in South Africa, which could be in respect of RE or EE. In terms of section $11 \mathrm{~A}$, the allowance is extended to pre-trade expenditure in respect of approved R\&D activities undertaken.

- $\quad$ Section $12 \mathrm{C}$ of the Income Tax Act grants accelerated depreciation allowances in respect of R\&D assets in the ratio 50:30:20 based on the cost of the assets. The cost of a building used for R\&D is, however, only allowed in equal portions over 20 years, in terms of section 13(1).

It appears as if equal focus is placed on the supply of, and demand for, electricity, with six tax instruments targeting each. Three instruments are focused on RE specifically - three on EE and two on R\&D. There are seven tax incentives to promote environmentally good behaviour, while there are only two disincentives that penalise environmentally bad behaviour. The majority (six) of the incentives are direct taxes and there is only one indirect tax incentive.

\section{Determining The Primary Focus Of Tax Instruments}

In this section, the tax instruments applied by the selected countries are compared in order to investigate whether the primary focus of the tax instruments is on the demand or on the supply of electricity, whether the governments primarily apply incentives or disincentives to achieve their objectives, whether they mostly apply direct or indirect taxes, and whether there is more focus on RE, EE, or R\&D.

\section{Primary Focus: Supply Or Demand}

A combination of supply-side and demand-side measures is expected; as such, a combination is necessary to effectively achieve reductions in emissions from electricity generation (Dippenaar, 2014). Tax instruments focused on the demand side - for example, EE may, in the short term, be more effective than tax instruments aimed at the supply side (Niesing, 2012). It is, however, not sufficient to target the demand side in isolation. In the long term, it is important to also target the supply side (Winkler, 2007). The number of tax instruments applied in each of the comparative countries targeting supply and demand is compared in Table 1.

Table 1: Number Of Instruments: Supply Or Demand

\begin{tabular}{|l|c|c|}
\hline Country & Supply & Demand \\
\hline Brazil & 7 & 4 \\
\hline China & 10 & 17 \\
\hline India & 14 & 6 \\
\hline South Africa & 6 & $\mathbf{3 8}$ \\
\hline Total & $\mathbf{3 7}$ & \\
\hline
\end{tabular}


The total number of tax instruments applied by the selected developing countries to target the supply and demand of electricity generation is approximately equal, as illustrated in Table 1. The tax instruments in South Africa and India appear to focus almost equally on the supply and demand of electricity, while the tax instruments in China primarily focus on the demand for electricity, especially on EMC projects. In Brazil, however, the focus appears to be slightly more on the supply of electricity.

It is clear that a combination of supply-side and demand-side measures is applied in each of the four selected developing countries and the focus appears to be different in each country. The next section compares the number of incentives and disincentives applied in each of the selected countries in order to determine their primary focus.

\section{Primary Focus: Incentives Or Disincentives}

According to Van Schalkwyk (2012), developing countries prefer incentives to promote green behaviour and appear to avoid using disincentives. Disincentives are presumably avoided by developing countries on the basis that such disincentives could damage development and growth prospects (KPMG, 2013b) and can affect a country's competitiveness (Anjum, 2008). Bennet and Moore (1981) also submitted empirical evidence demonstrating that incentives are generally more effective in swaying customers towards RE and EE than environmental taxes. The number of tax incentives and disincentives applied in each of the comparative countries is as follows:

Table 2: Number Of Instruments: Incentives Or Disincentives

\begin{tabular}{|l|c|c|}
\hline Country & Incentives & Disincentives \\
\hline Brazil & 7 & 0 \\
\hline China & 19 & 0 \\
\hline India & 15 & 1 \\
\hline South Africa & 7 & 2 \\
\hline Total & $\mathbf{4 8}$ & $\mathbf{3}$ \\
\hline
\end{tabular}

The primary focus in all the countries studied appears to be the application of incentives, rather than disincentives, as illustrated in Table 2. All four of the selected countries appear to strongly favour the application of incentives as opposed to disincentives, which is in line with the findings of other researchers. The next section compares the number of direct and indirect tax instruments applied in each of the selected countries in order to determine their primary focus.

\section{Primary Focus: Direct Or Indirect Taxes}

According to Atkinson (1977), one of the oldest issues of tax policy is the choice between direct and indirect taxes and, over centuries, countless views have been expressed on this controversial subject. In practice, there has been a shift from direct to indirect taxes to help solve the economic uncertainty, especially in developing countries (PWC, 2013c). Mahdavi (2008) also submitted that, despite the revenue-raising capability of different tax revenue compositions (direct or indirect taxes), the composition may not necessarily be desirable to the extent that the tax system "overuses" some tax types and "underuses" others. An investigation into the focus of tax instruments on direct or indirect taxes is therefore warranted in order to avoid the overuse or underuse of direct or indirect taxes. Table 3 compares the number of direct and indirect tax incentives applied in each of the comparative countries. For purpose of classification of tax instruments, direct taxes refer to corporate income tax and enterprise tax, whilst indirect taxes include customs and excise duties, environmental levies, state and federal VAT, business tax, federal social contributions, sales tax and service tax.

Table 3: Number Of Incentives: Direct Or Indirect Taxes

\begin{tabular}{|l|c|c|}
\hline Country & Direct & Indirect \\
\hline Brazil & 3 & 4 \\
\hline China & 10 & 9 \\
\hline India & 6 & 9 \\
\hline South Africa & 6 & 1 \\
\hline Total & $\mathbf{2 5}$ & $\mathbf{2 3}$ \\
\hline
\end{tabular}

Copyright by author(s); CC-BY 
The selected developing countries appear to place nearly equal focus on direct and indirect tax incentives, with the exception of South Africa, where hardly any indirect tax incentives are used, as illustrated in Table 3. The next section compares the number of tax instruments applied in each of the selected countries that specifically target $\mathrm{RE}, \mathrm{EE}$ and R\&D.

\section{Primary Focus: RE, EE Or R\&D}

Ahuja and Tatsutani (2009) submit that EE is often the preferred approach as these improvements offer the largest and least costly emissions reduction potential in the short term and small, incremental and cumulative improvements in EE over long periods can deliver enormous benefits. Tax instruments have also been found to be effective in promoting RE when combined with other instruments (CRS, 2005) and it is becoming more common for government policies all over the world to combine EE and RE measures (KPMG, 2013a \& 2013b). This is also evident in the study as all four countries selected, with the exception of China, make almost equal use of RE and EE measures. Many countries also apply tax instruments to encourage R\&D since innovation is critical to governments' green policy objectives (KPMG, 2013b). The number of tax instruments applied in each of the comparative countries, targeting RE, EE and R\&D, is presented in Table 4. Only tax instruments specifically targeting these fields were considered. Tax instruments of a more general nature that could also apply to other fields - for example, electricity generation from non-renewable sources, were not taken into account.

Table 4: Number Of Instruments: Renewable Energy, Energy Efficiency Or Research

\begin{tabular}{|l|c|c|c|}
\hline Country & RE only & EE only & R\&D only \\
\hline Brazil & 2 & 0 & 3 \\
\hline China & 2 & 8 & 4 \\
\hline India & 4 & 2 & 5 \\
\hline South Africa & 3 & 3 & 2 \\
\hline Total & $\mathbf{1 1}$ & $\mathbf{1 3}$ & $\mathbf{1 4}$ \\
\hline
\end{tabular}

As illustrated in Table 4, there seems to be almost equal focus on RE, EE and R\&D in the countries studied, except in China where the number of tax instruments specifically targeted at EE significantly exceeds the number of instruments specifically targeted at $R E$ and $R \& D$. The reason for this is the large number of incentives available to EMC projects. Based on the findings, Brazil uses no tax instruments to target EE.

A combination of tax instruments relating to RE, EE and R\&D were identified in the selected countries. Brazil is the only country with no tax instruments that specifically target EE and China is the only country that appears to strongly favour EE.

\section{CONCLUSION}

This study postulates that it is useful to compare the tax instruments applied by Brazil, China, India and South Africa to address the challenges of high emissions from electricity generation, since they are all developing countries and there is increased pressure on developing countries to increase their environmental protection efforts and embark on more sustainable development pathways. There is also an ongoing shift in RE activity from developed to developing countries. Other similarities between the selected countries are:

- $\quad$ They all form part of the BRICS association of major emerging economies.

- $\quad$ They all have electricity supply shortages.

- $\quad$ They all have very high emissions from the burning of fossil fuels.

- $\quad$ The governments of all four countries are committed to reduce their countries' emissions.

- $\quad$ They all are non-Annex countries in terms of the Kyoto Protocol.

- $\quad$ They all are members of BASIC.

- $\quad$ They all have made significant investments in RE since 2012.

- They are all fairly active in the application of tax instruments to achieve green policy objectives. 

the study:

Based on the study performed, the following answers are submitted for the specific research questions of

- The tax instruments in South Africa and India focus almost equally on the supply and demand of electricity, while the tax instruments in China primarily focus on the demand side, with a large number of incentives provided in respect of EMC projects. In Brazil, however, the focus of the tax instruments appears to be slightly tilted towards the supply of electricity.

- The primary focus in all the countries studied appears to be the application of incentives rather than disincentives. The selected developing countries appear to prefer incentives to promote green behaviour and tend to avoid disincentives.

- The focus of the tax incentives implemented by the countries studied appears to be equally on the application of direct and indirect taxes, with the exception of South Africa where hardly any indirect tax incentives are used.

- $\quad$ There seems to be almost equal focus on RE, EE and R\&D in the countries studied, except in China where the number of tax instruments specifically aimed at EE significantly exceeds the number of instruments specifically aimed at RE and R\&D. In Brazil, no tax instruments specifically targeting EE were found to be used.

It could be worthwhile for the policymakers of each of the selected developing countries to consider the tax instruments applied by the comparative countries. This comparison could identify other areas into which a country could also expand or could identify specific instruments worth considering. In particular, it was noted that Brazil was the only country that did not have any tax instruments in support of EE that could be investigated. China was noted to have a disproportionate focus of tax instruments on the demand for electricity, compared to the other selected countries. South Africa was noted to have a disproportionate focus of tax instruments on direct taxes, compared to the other selected countries, which had a balanced focus on both direct and indirect taxes.

\section{AUTHOR INFORMATION}

Mareli Dippenaar, CA (SA); MAcc Taxation (Stellenbosch); lecturer at Stellenbosch University in accounting. Email: (lagrange@sun.ac.za).

Rudie Nel, CA (SA); MCom Taxation (Pretoria); senior lecturer at Stellenbosch University in taxation.

\section{REFERENCES}

1. Ahuja, D., \& Tatsutani, M. (2009). Sustainable energy for developing countries. S.A.P.I.E.N.S., 2(1).

2. Anjum, N. (2008, April 28). Prospects of green-taxes in developing countries. Business and Finance review.

3. Ashiabor, H. (2005). Fostering the Development of Renewable Energy through Green Taxes and Other Instruments. Bulletin for International Taxation, 59(7), 295-305.

4. Atkinson, A. B. (1977). Optimal taxation and the direct versus indirect tax controversy. Canadian Journal of Economics, 10(4), 590-606.

5. Bana, S. (2012). India powers ahead. Renewable Energy Focus, May/June, 20-24.

6. Bennet, P., \& Moore, N. (1981). Consumer Preferences for Alternative Energy Conservation Policies: A Tradeoff Analysis. Journal of Consumer Research, 8(3), 313-321.

7. Bierbaum, R., \& Friedman, R. M. (1992). The Road to Reduced Carbon Emissions. Issues in Science and Technology, 8(2), 58-65.

8. $\quad$ Bird, R. M. (2008). Tax Challenges Facing Developing Countries. Rotman Institute for International Business Working Paper Series IIB Paper no. 9. Toronto: University of Toronto Joseph L. Roman School of Management.

9. Bloomberg New Energy Finance. (2011, January 12). Solar surge drives record clean energy investment in 2011. Bloomberg New Energy Finance.

10. Bloomberg New Energy Finance. (2013). Global Trends in Renewable Energy Investment 2013. Frankfurt: Frankfurt School of Finance \& Management.

11. Buffkins, S. (2012, January 20). What will the future electricity generating landscape be like? Part 1. Psiclone News. [Online]. Retrieved September 6, 2013: http://www.psiclone.co.za/index.php?option=com_k2\&view=item\&id=81: what-will-the-future-electricity- 
generating-landscape-be-like? \&Itemid=235.

12. Calitz, E., Wallace, S., \& Burrows, L. (2013). The impact of tax incentives to stimulate investment in South Africa. Stellenbosch Economic Working Papers 19/13. Stellenbosch: University of Stellenbosch.

13. Chacon, L. B. (2013). Long-term contracting the way to renewable energy investment: lessons from Brazil applied to the United States. Emory Law Journal, 62(6), 1563-1612.

14. Chadbourne \& Parke LLP. (2010). China Renewables Update: new regulatory and policy initiatives focused on wind, solar photovoltaic and biomass industries. [Online]. Retrieved May 14, 2014: http://www.chadbourne.com/China_Renewables_Update_Sept2010_projectfinance/.

15. Chandrasekar, B., \& Kandpal, T. C. (2004). Effect of financial and fiscal incentives on the effective capital cost of solar energy technologies to the user. Solar Energy, 78(2), 147-156.

16. CRS (Centre for Resource Solutions). (2005). International Tax Incentives for Renewable Energy: Lessons for Public Policy (draft report). San Francisco.

17. Dasgupta, S. (2009, November 28). Copenhagen conference: India, China plan joint exit. The Times of India.

18. Deloitte. (2013a). 2013 Global Survey of $R \& D$ Tax Incentives. [S.1.].

19. Deloitte. (2013b). Taxation and Investment in China 2013. [S.1.].

20. Dippenaar, M. (2014). The role of tax instruments in reducing emissions from electricity generation in selected developing countries - a comparative study. Unpublished master's thesis, University of Stellenbosch.

21. Dolowitz, D. P., \& Marsh, D. (2000). Learning from Abroad: The Role of Policy Transfer in Contemporary Policy-Making. Governance: An International Journal of Policy Administration, 13(1), 5-24.

22. Easson, A., \& Zolt, E. M. (2002). Tax Incentives. Working Paper. World Bank Institute, 1-35.

23. EY. (2013a). Worldwide corporate tax guide 2013-14. [S.1.].

24. $\quad$ EY. (2013b). Worldwide R\&D incentives reference guide 2013-2014. [S.1.].

25.

26.

Farah, A. G. V. (2013, July 1). Tax Reduction for Infrastructure Development in Brazil. The Brazil Business. Freitas, I. M. B., Dantas, E., \& Iizuka, M. (2011). The Kyoto mechanisms and the diffusion of renewable energy technologies in the BRICS. Energy Policy, 42, 118-128.

27. Giraudet, L., Guivarch, C., \& Quirion, P. (2011). Comparing and Combining Energy Saving Policies: Will Proposed Residential Sector Policies Meet French Official Targets? The Energy Journal, 32(Special Issue), 213242.

28. International Energy Agency. (2012). Understanding Energy Challenges in India. [S.1.].

29. Junfeng, S., Pengfei, G., \& Hu, G. (2010). China Wind Power Outlook. [S.1.]: Global Wind Energy Council.

30. KPMG. (2009). Corporate Income Tax Incentives for Clean Development Mechanism Projects. China alert: Tax and regulatory developments, Issue 34.

31. KPMG. (2011). Tax milestone in energy saving industry - Second batch of energy service companies released. China alert: Energy \& Natural Resources Focus, Issue 2.

32. KPMG. (2012). Securing R\&D Tax Incentives in China. Hong Kong.

33. KPMG. (2013a). Taxes and incentives for renewable energy. [S.1.].

34. KPMG. (2013b). The KPMG Green Tax Index 2013. [S.1.].

35. KPMG. (2013c, July 8). Revamp of Special Economic Zones Exemption under Service tax. KPMG Flash News.

36. Lomas, U. (2012, July 23). Dutch Investment Tax Boosts Renewable Energy. Tax News. [Online]. Retrieved April 17, 2014: http://www.tax-

news.com/news/Dutch_Investment_Tax_Boosts_Renewable_Energy_56469.html.

37. Mahdavi, S. (2008). The level and composition of tax revenue in developing countries: Evidence from unbalanced panel data. International Review of Economics \& Finance, 17(4), 607-617.

38. May, P. H. (2008). Overcoming Contradictions Between Growth and Sustainability: Institutional Innovation in the BRICS. Chinese Journal of Population Resources and Environment, 6(3), 3-13.

39. Metz, B., Davidson, O. R., Bosch, P. R., Dave, R., \& Meyer, L.A. (Eds.). (2007). Climate Change 2007: Mitigation. Contribution of Working Group III to the Fourth Assessment Report of the Intergovernmental Panel on Climate Change. Cambridge: Cambridge University Press.

40. Ministry of Commerce and Industry. (2009). Special Economic Zones in India. [Online]. Retrieved July 12, 2014: http://sezindia.nic.in.

41. Ministry of Environment and Forests. (2010). India: Greenhouse Gas Emissions 2007. New Delhi.

42. $\quad$ Ministry of Mines and Energy. (2013). Brazilian Energy Balance Year 2012. Rio de Janeiro.

43. MNRE (Ministry of New and Renewable Energy). (2013). Annual Report: 2012-13. New Delhi.

44. Nathan-MSI Group. (2004). Effectiveness and Economic Impact of Tax Incentives in the SADC Region. [S.l.:s.n.].

45. Niesing, G. (2012). Assessing the barriers companies face towards the implementation of corporate energy efficiency strategies. Unpublished master's thesis, North-West University. 
46. Nteo, L. D. (2012). Role of market based instruments in transitioning to a low carbon economy: experiences from BRICS countries and lessons for South Africa. Unpublished master's thesis, Gordon Institute of Business Science University of Pretoria.

47. PWC. (2012, April). Research and development in the BRICS. Global R\&D Tax News.

48. $\quad$ PWC. (2013a). Doing Business and Investing in Brazil. [S.1.].

49. $\quad$ PWC. (2013b). Worldwide Tax Summaries: Corporate Taxes 2013/14. [S.1.].

50. PWC. (2013c). Shifting the balance from direct to indirect taxes: bringing new challenges. Tax policy and administration - Global perspectives June 2013. [S.1.].

51. Republic of South Africa. (1962). Income Tax Act 58 of 1962. [Laws.] Pretoria: Government Printer.

52. Republic of South Africa. (1964). Customs and Excise Act 91 of 1964. [Laws.] Pretoria: Government Printer.

53. Republic of South Africa. Department of Minerals and Energy. (2004). White Paper on Renewable Energy November 2003. Government Gazette no. 26169, 14 May.

54. Republic of South Africa. National Treasury. (2006). Draft Policy Paper: A framework for considering marketbased instruments to support environmental fiscal reform in South Africa. Pretoria: Government Printer.

55. Republic of South Africa. Department of Minerals and Energy. (2009). National Energy Efficiency Strategy for South Africa, March 2005, Reviewed October 2008. Government Gazette no. 32249, 22 May.

56. Republic of South Africa. (2012). South Africa Yearbook 2011/12. Pretoria: Government Printer.

57. Rewave Infra Solutions. (2013). Wind Power in India: Industry Information Insights 2013. [S.1.:s.n.].

58. Seligsohn, D., Heilmayr, R., Tan, X., \& Weischer, L. (2009). China, The United States, and the Climate Change Challenge. World Resource Institute, WRI Policy Briefs, October.

59. Singh, A. (2007). A market for renewable energy credits in the Indian power sector. Renewable and Sustainable Energy Reviews, 13(3), 643-652.

60. Sinha, A. (2011, February/March). Renewable Energy in India: Scope for Foreign Investment. Alternative Energy eMagazine. [Online]. Retrieved July 6, 2014: www.altenergymag.com/emagazine/2010/12/renewableenergy-in-india-scope-for-foreign-investment/1654.

61. Todaro, M. P. (2000). Economic Development. $7^{\text {th }}$ ed., Massachusetts: Addison-Wesley.

62. Tollefson, J. (2013, June 5). Brazil reports sharp drop in greenhouse emissions. Nature: international weekly journal of science. [Online]. Retrieved January 28, 2014: http://www.nature.com/news/brazil-reports-sharp-dropin-greenhouse-emissions-1.13121.

63. UNFCCC (United Nations Framework Convention on Climate Change). (2014). Kyoto Protocol. [Online]. Retrieved February 2, 2014: http://unfccc.int/kyoto_protocol/items/2830.php.

64. UNIDO (United Nations Industrial Development Organisation). (2009). Scaling up Renewable Energy in Africa: $12^{\text {th }}$ Ordinary Session of Heads of State and Governments of the African Union. Austria.

65. United Nations Environment Programme. (2012). Year book: emerging issues in our global environment. Nairobi.

66. Upadhyaya, P. (2010). Is emission trading a possible policy option for India? Climate Policy, 10(5), $560-574$.

67. Van Schalkwyk, S. G. (2012). An international comparison of environmental tax with an emphasis on South Africa. Unpublished master's thesis, University of Pretoria.

68. Winkler, H. (2005). Renewable energy policy in South Africa: policy options for renewable electricity. Energy Policy, 33(1), 27-38.

69. Winkler, H. (2007). Energy policies for sustainable development in South Africa. Energy for sustainable development, $X I(1), 26-34$.

70. World Bank. (2013). World Development Indicators 2013. Washington, DC: World Bank.

71. Zee, H. H., Stotsky, J. G., \& Ley, E. (2002). Tax Incentives for Business Investment: A Primer for Policy Makers in Developing Countries. World Development, 30(9), 1497-1516.

72. Zhang, X., Chang, S., Huo, M., \& Wang, R. (2009). China's wind industry: policy lessons for domestic government interventions and international support. Climate Policy, 9(5), 553-564. 